\title{
Schwäbische Alb (Swabian Alb) Biosphere Reserve
}

\author{
Rüdiger Jooß
}

\section{Abstract}

On 22 March 2008, the Schwäbische Alb Biosphere Reserve (BR) was founded and designated by UNESCO in May 2009. It was the $15^{\text {th }}$ BR in Germany and the first of its kind in the Land of Baden-Württemberg.

After a brief preparatory process of just three years, there are now 29 towns and municipalities, three administrative districts, two government regions, as well as the federal republic of Germany (Bundesanstalt für Immobilienaufgaben) as owner of the former army training ground in Münsingen involved in the BR, which covers $850 \mathrm{~km}^{2}$ and has a population of ca. 150000.
Profile

Protected area

UNESCO BR Schwäbische Alb

Mountain range

Low mountain range

Country

Germany

\section{Location}

The low mountain range of the Swabian Alb belongs to one of the largest karst areas in Germany. In the northeast it continues in the Franconian Alb and towards the southwest in the Swiss Jura. In BadenWürttemberg the Swabian Alb is a characteristic major landscape. For around $100 \mathrm{~km}$, a steep escarpment of the Swabian Alb, the so-called Albtrauf, rises 300-400 metres above the foothills in the north. The Albtrauf links into the plateau of the Swabian Alb, which presents a highly varied, crested relief in the north, while mild undulations dominate in the southern part. The Swabian Alb forms the European watershed between Rhine and Danube.

\section{Climate}

The Swabian Alb lies in the cool, humid, temperate zone of westerly winds. The land at the foot of the $\mathrm{Alb}$ is slightly warmer, with an annual average temperature of $8.0^{\circ} \mathrm{C}$, and allows wine-growing on southfacing slopes. Here the frost-free period per year is usually about a month longer than on the Alb plateau, where it is considerably cooler, with an annual average temperature of $6.7^{\circ} \mathrm{C}$. Average precipitation varies between 750 and $1050 \mathrm{~mm} /$ year. Most rain falls in the summer months of June and August, and in November. The area along the Albtrauf has the highest precipitation. The ca. $350 \mathrm{~m}$ rise forces humid air, which mainly comes from the west and northwest, to fall as rain. In the lee of the Albtrauf, precipitation declines with distance to the escarpment.

\section{Natural landscapes}

The BR area covers the full range of the highly varied landscapes of the Swabian Alb, from the foothills to the Albtrauf to the plateau.

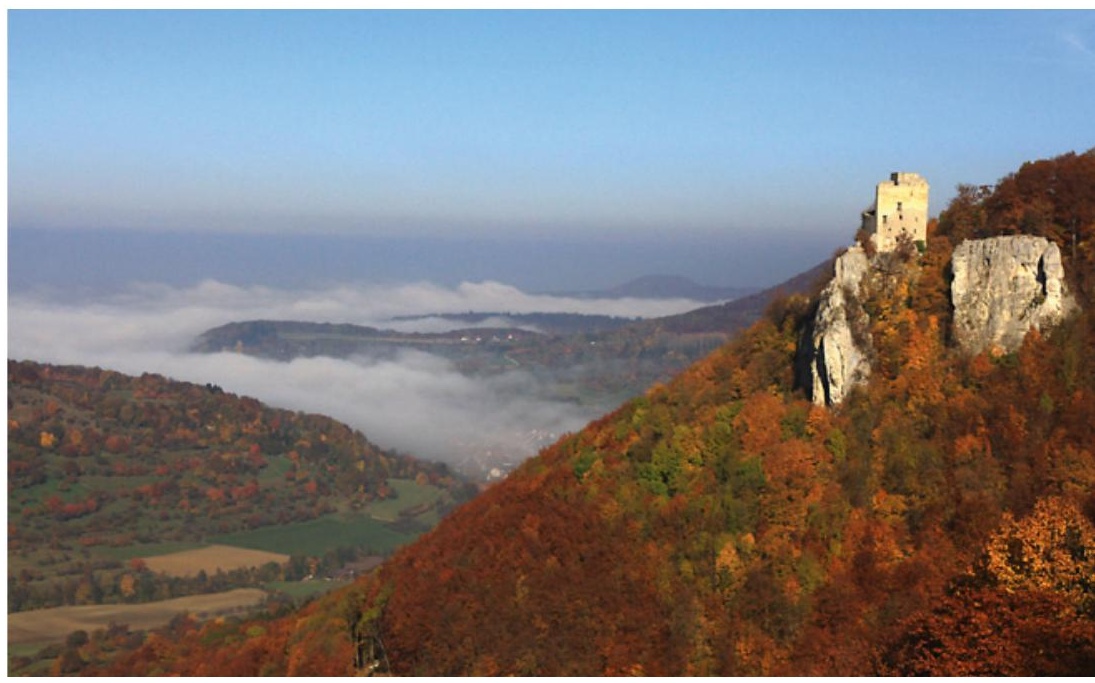

Figure 1 - Fort Reussenstein in the Schwäbische Alb Biosphere Reserve. (C) D. Ruoff

\section{The foothills of the Alb}

This area is dominated by extensive meadow orchards. These are meadows with fruit trees (apple, pear, plum, cherry, walnut) planted at generous intervals. They were created mainly in the $18^{\text {th }}$ and $19^{\text {th }}$ century to improve the vitamin supply of the population, esp. in the winter months, with dried fruit and compotes. Their enormous ecological significance lies in the many hollow trees used as shelter by many bird species, such as the collared flycatcher (Ficedula albicollis), the Eurasian wryneck (Jynx torquilla) and the little owl (Athene noctua), as well as by small mammals like dormice (Glis glis) and bats. The meadows are also home to a great variety of plants and insects, which in turn provide food for higher animals. The diversity of the meadows is the result of mainly extensive use, as the presence of the fruit trees inhibits the use of machines. Meadow orchards were traditionally created in a ring around the villages and have in recent decades often fallen victim to settlement expansions and 


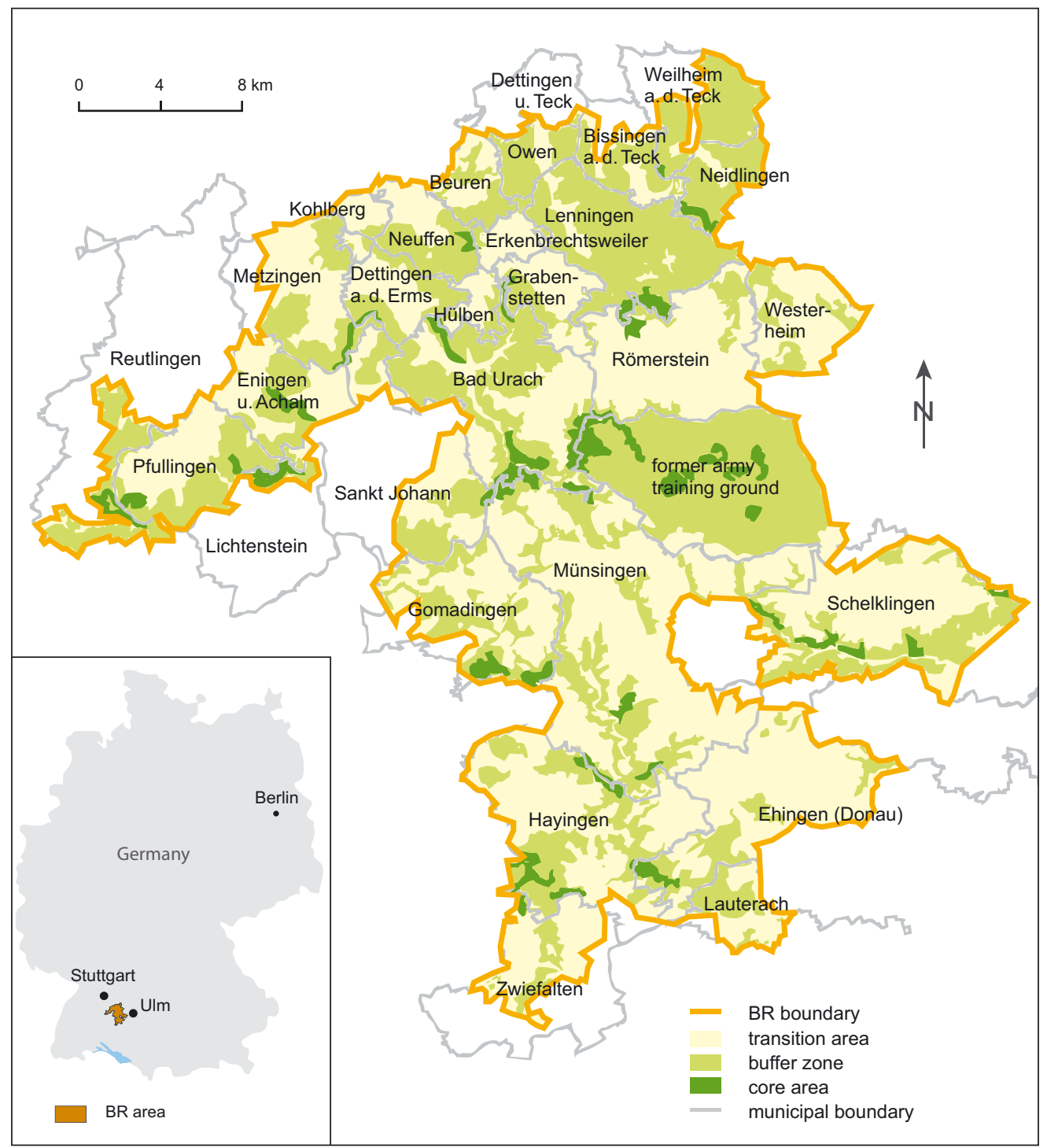

Figure 2 - Location of BR Schwäbische Alb, Germany. Maps created on the basis of VIVA IDEA, Stuttgart. Map sources: Federal office of Geoinformation and Spatial Development

ring roads. In many cases the production of traditional meadow orchard produce, such as fruit juices, distilled drinks and stewed fruit, is no longer profitable within today's framework conditions. This is where the BR can help sustain a unique habitat by promoting the sale of meadow orchard products through new product ideas and by raising awareness.

\section{The Albtrauf}

The striking escarpment of the Albtrauf is dissected by deep river valleys and spurs that reach far into the land below, which make for a very attractive and varied landscape. The steep slopes are dotted with rocks and largely covered with trees. Beech forests dominate (European beech, Fagus sylvatica), succeeded in cooler and humid locations by typical canyon societies of ash, sycamore maple and elm (Fraxinus excelsior, Acerpsendoplatanus, Ulmus glabra). Very dry locations have scree forests of small-leaved and large-leaved lime and hornbeam (Tilia cordata, Tilia platyphyllos, Carpinus betulus).
On limestone rocks, esp. in sunny expositions, specialized plant societies occur that are adapted to dryness and heat and include many endangered species, for instance Cheddar pink (Dianthus gratianopolitanus), yellow whitlow-grass (Draba aizoides) or white mountain saxifrage (Saxifraga paniculata). Peregrine falcon (Falco peregrinus) and Eurasian eagle-owl (Bubo bubo) like rock shelters as safe breeding places. The limestone rocks contain many caves used in winter by bat species such as the barbastelle (Barbastella barbastellus) and the greater horseshoe bat (Rhinolophus ferrumequinum).

The big differences in elevation and the great variety on a small spatial scale make for a very characteristic and unusually attractive landscape. Walkers are rewarded with fascinating views into the foothills. Fortresses and ruins are found all along the Albtrauf and make popular destinations for shorter hikes. In addition there are waterfalls, karst springs and show caves to complement the attractions of the Alb landscape. The Albtrauf with its many fortresses and ruins, and its wooded slopes and ravines is one of the unique 
characteristics that convinced UNESCO to designate the Swabian Alb BR.

\section{The Alb plateau}

On the Alb plateau, forests, especially on low crests, alternate with fields and meadows in a pattern of small patch sizes. The characteristic and ecologically valuable juniper heaths came about through centuries of sheep keeping. Selective browsing and trampling by sheep and goats prevent scrub encroachment in the heaths, thus preserving high species diversity, e.g. silver thistle (Carlina acaulis) and pasque flower (Pulsatilla vulgaris), on poor soils. Grazing animals avoid the typical juniper (Juniperus communis) because of its hard, pointed leaves. Traditional itinerant shepherding plays a vital role in the exchange of species between pastures through sheep transporting bits of plants and small animals in their coats.

While sheep keeping was still quite profitable in the $19^{\text {th }}$ century, it cannot survive today without subsidies from agricultural environment programmes. In today's landscape of settlements and transport infrastructure, it has become impossible to sustain the traditional system of large-scale transhumance, which meant spending the winter in warmer regions on Lake Constance or in the Rhine valley. The BR administration supports projects to encourage the consumption of lamb, and the use of wool and juniper products, such as bangles, necklaces or household items, in an effort to maintain shepherding and with it the juniper heaths. Preserving dry habitats such as juniper heaths or poor meadows is vital because the Swabian Alb is one of the overarching ecologic corridors for dry habitat species in Central Europe.

\section{The Großes Lautertal}

The karst processes of the limestone have left the Alb plateau largely devoid of bodies of water. This makes the valley of the Große Lauter river, roughly $35 \mathrm{~km}$ in length, a special landscape feature of the Swabian Alb. It meanders through riverine meadows, past romantic villages, towards the Danube. The valley slopes are covered in juniper heaths and dotted with rugged rocks, often crowned by a fortress or ruins. A cycle path follows the river, at certain times of the year canoeing is tolerated. In the southern part of the Großes Lautertal, no roads disturb the enjoyment of nature of walkers on picturesque paths.

\section{Former army training ground Münsingen}

Another special feature of the BR is the former army training ground at Münsingen. It was used by the military for more than a hundred years until its closure in 2005. The 6700 ha plot, not dissected by any roads, feels like a typical $19^{\text {th }}$ century landscape. Extensive pastures with large herds of sheep, picturesque

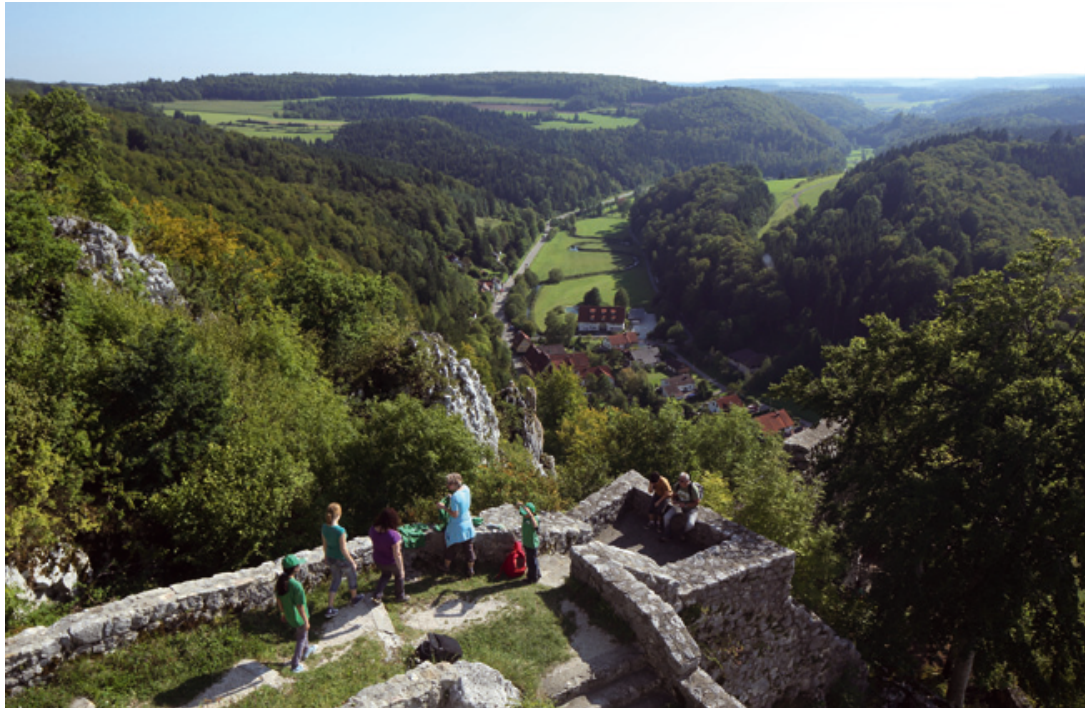

Figure 3-Lautertal. (C) R. Koch

clumps of willow, wood pastures and fluid transitions between forest and open land let visitors experience a landscape from the past. In densely populated German Land of Baden-Württemberg, this is one of the few places to experience nature without any disturbance from roads or settlements. Two thirds of the area are used for grazing sheep and it is also home to the only occurrence of many rare plants and animals in Baden-Württemberg. These include wheatear

\section{Infobox}

Location: South-western Germany, Baden-Württemberg

Administration: The office of Schwäbische Alb BR is a subsidiary of the Dept. of the Environment of the Regierungspräsidium Tübingen (a regional authority in Baden-Württemberg)

Established: 22.03.2008, designation by UNESCO in May 2009

Size: 85269 ha

Landscape: Varied cultural landscape of the low mountain range Swabian Alb, elevation: Ermstal 329 m, Römerstein 872 m

Objectives: Sustainable regional development, preservation of the attractive cultural landscape shaped by traditional land use, recreation, sustainable development education, research

Zoning: Core area: $3.1 \%$; buffer zone: $41.5 \%$; transition area: $55.4 \%$

Visitors: Nearly 1 million overnight stays in BR municipalities in 2011 (source: Statistisches Landesamt Baden-Württemberg)

Main information centre: Biosphärenzentrum Schwäbische Alb in Münsingen (30000 visitors in 2011 and 2012); 15 additional information points dotted across the BR area, integrated in existing tourist facilities

Special features: Albtrauf with wooded slopes and ravines, meadow orchards, juniper heaths, former army training ground at Münsingen, many fortresses and ruins, part of GeoPark Swabian Alb (under the auspices of UNESCO)

\section{Contact}

Geschäftsstelle Biosphärengebiet Schwäbische Alb, Von der Osten Straße 4, 6 (Altes Lager), 72525 Münsingen, Germany

Tel. +49738193293810

biosphaerengebiet@rpt.bwl.de www.biosphaerengebiet-alb.de 


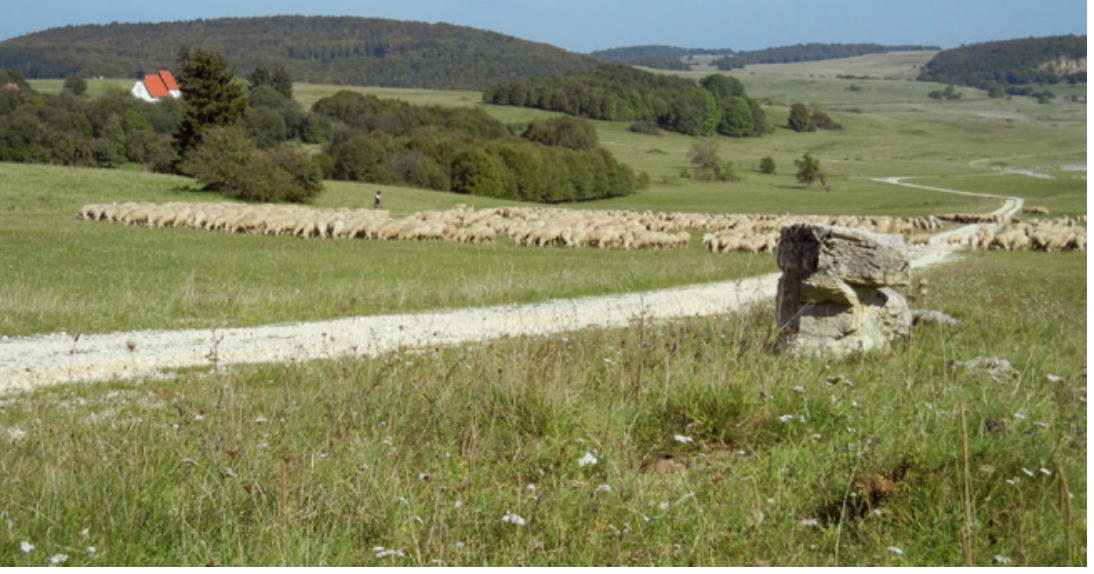

Figure 4 - Former army training ground at Münsingen. (C) Schwäbische Alb Biosphere Reserve Administration

(Oenanthe oenanthe), woodlark (Lullula arborea), whinchat (Saxicola rubetra) and the mountain grasshopper (Stauroderus scalaris). Walking and cycling is allowed on the paths marked in yellow. The former village of Gruorn had to be abandoned by the inhabitants in 1938. Today the church and cemetery still exists, as does the school, which is now a museum.

\section{Special cultural features}

\section{Long settlement history}

As far back as the stone age the caves of the Swabian Alb provided shelter for humans. In several caves there are findings from the times of Neanderthal man (Homo sapiens neanderthalensis) roughly 100000 years ago. The findings from the Hoble Fels (hollow rock) in the immediate vicinity of the BR have become famous and can be attributed to modern man (Homo sapiens sapiens). The Venus of Hoble Fels, a female statue of mammoth ivory, is currently rated as the world's oldest sculpture of a human figure. It was created around 35000-40000 years ago at the time of the Aurignacian culture. The world's oldest musical instrument also stems from that period: it is a bone flute, made from the ulna of a griffon vulture, and has been almost completely reconstructed. On a guided tour through the cave you can hear the recording of a similar instrument - an unforgettable experience.

A special feature from the time of the Celts is the township (oppidum) of Heidengraben at the Albtrauf. The spur near Grabenstetten, almost completely surrounded by steep escarpments, was fortified at the upper edge of its tip with a rampart and a ditch towards the south. Access was only possible through so-called pincer gates. The V-shape allowed firing at attackers from both sides in a pincer movement. In the $5^{\text {th }}$ century, at the transition from the Hallstatt to the Latène period, several thousand people lived here - a large town for the time. Today visitors can walk around and inspect a reconstructed pincer gate, ditches and bulwarks as well as burial mounds.

Unique to the Schwäbische Alb BR is its wealth of fortresses. Many of them were built during the Stauffer period $\left(12^{\text {th }}-13^{\text {th }}\right.$ century) along the Albtrauf and in the valley of the Große Lauter. Fortified castles with massive walls and high towers were erected in exposed locations, often atop a rocky outcrop. Today visitors can enjoy a wide range of well-preserved fortresses, some of them, e.g. Burg Teck and Hohenneuffen, with inns, or discover and explore ruins along eerie paths. What all former residences have in common are impressive panoramic views across the Swabian Alb.

\section{Urban agglomerations within the BR}

With $7 \%$ of the total area or $35 \%$ of the development zone, urban agglomerations take up quite a large part of Schwäbische Alb BR. After Wienerwald BR in Austria, this is only the second BR worldwide to include urban agglomerations and to be located fairly close to a federal state capital, in this case Stuttgart. Such a location has its pros and cons. On the plus side, there is a large potential market nearby for the sale of regional produce, which contributes to the preservation of traditional land use biotopes such as meadow orchards and juniper heaths. In the coming years, targeted marketing efforts will be made to open up this market further. On the down side, there is the dense traffic from commuters, plus day trippers at the weekends. Here it is vital to improve public transport on the basis of existing train lines and to integrate it with innovative approaches, for instance, from e-mobility. Initial signs are that the hilly terrain of the Swabian Alb is well suited for the use of e-bikes in both commuting and leisure travel as an environment-friendly mobility option.

\section{Zoning}

\section{Core areas - protection against use}

At $3.1 \%$ of the total area, core zones only just meet the requirements of the German MAB criteria of 3\% for areas where nature is to develop without human intervention as far as possible. Almost all core areas of the BR are in forests, mostly on steep slopes, canyon forests or scree forests at the Albtrauf or in the Kuppenalb (crest Alb). Some paths have been preserved to allow access to the core area, but many forest paths have been abandoned to allow unimpeded growth of tomorrow's virgin forests.

\section{Buffer zones - protection through use}

At $41.5 \%$, the buffer zones are much more generous than the MAB criteria require (min. 10\%). They are designed to preserve and develop the character and special features of the highly varied cultural landscape of the Swabian Alb with its highly diverse animal and plant societies. These include the meadow orchards, juniper heaths, extensively used species-rich 
grassland and richly structured forests, all of which are a high conservation priority. Most of them came about through traditional forms of land use that are no longer economically viable. A major challenge for the $\mathrm{BR}$ is preserving such habitats through subsidies and through ensuring the continuation of agri- and silvicultural use adapted to these landscapes.

Transition areas - sustainable regional development

The development zones cover $55.4 \%$ of the total area and represent the more intensively used and the settlement areas. Several model projects are in place to promote sustainable development here, which would take into account the environment, society and the economy in equal measure. This might be settlement development that would first use inner-municipal potential before sealing new areas outside existing villages. The expansion of short-distance public transport and the implementation of innovative concepts for e-mobility would benefit both the local population and visitors of the BR. Targeted advice on energy efficiency and energy saving for municipalities, enterprises and private households serve climate control and reduce energy costs at the same time.

\section{The framework concept}

The UNESCO requirements envisage BRs to develop a framework concept after they have been set up. Starting with an analysis of the status quo, it lists the development options for the area and ways of implementing them. The Schwäbische Alb BR chose a highly participatory approach. Twelve working groups developed the main input on the following themes: conservation, agriculture (subdivided into shepherding, meadow orchard fruit growing and wine growing), forestry and hunting, environmental and climate protection, municipal development, planning and transport, tourism and hospitality, education for sustainable development, historical-cultural heritage, and marketing and PR. Each working group included 10-20 representatives from authorities, associations and practitioners. In four workshops the working groups formulated visions of how the BR will have developed in their respective sphere within 10 years. From these visions they distilled concrete development aims and project ideas for attaining them. From the many project proposals, they jointly selected priority projects for the BR office to work on. Several public events and forms of participation, such as film, painting and short story competitions, involved the local population who could also submit project proposals.

This framework concept involves experts and citizens to an extent not seen in any German BR to date. The BR administration co-finances the implementation of the concept with $€ 200000$ per year and endeavours to raise additional funds.

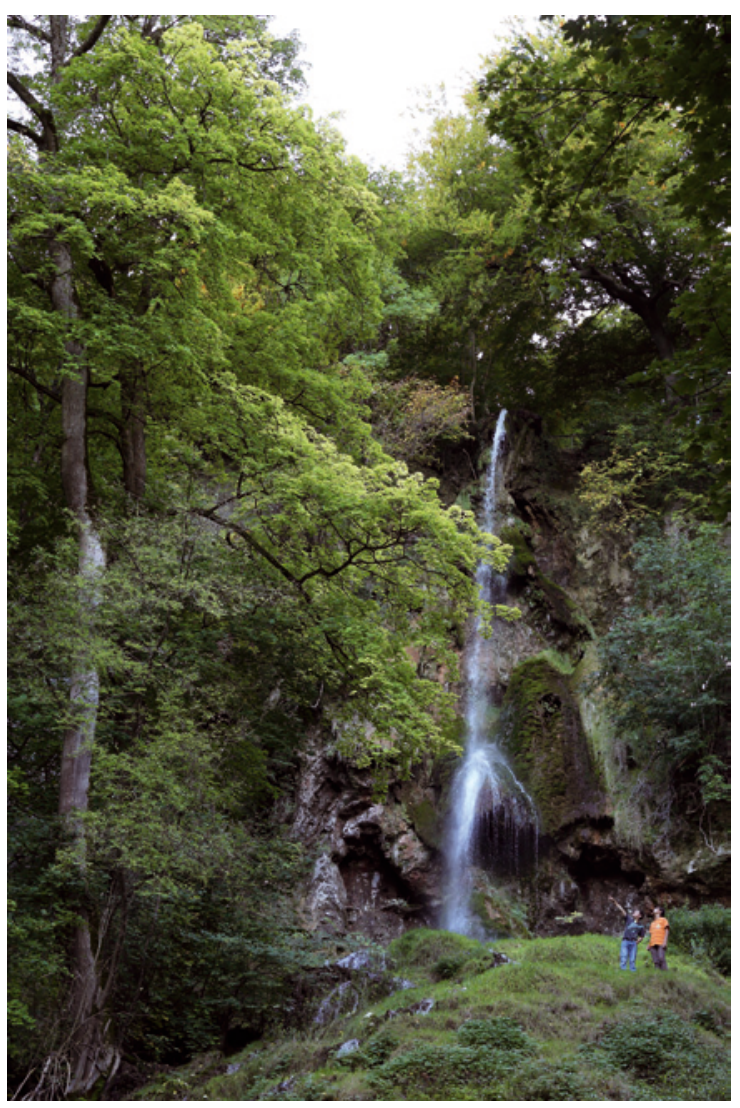

Figure 5 - Urach waterfall. (C) R. Koch

\section{The partner initiative}

Establishing the Partner Initiative in the BR is a first successful step in promoting sustainable regional development. The Partner Initiative is implemented throughout Germany in national parks, BRs and nature parks. It aims to attract actors from the protected areas into the partner network. They all adhere to jointly developed quality and environmental standards in their range of products. Currently the Schwäbische Alb BR has 98 certified partners. About half of them are specially trained nature and landscape guides, around a quarter are hotels or restaurants. Nearly a fifth are partners involved in information and education centres, and another fifth are processing businesses such as bakeries, pasta producers, wool processors, breweries or processors of meadow orchard fruit.

Restaurant and hotel partners are required to fulfil criteria such as providing a broad range of regional dishes from the BR and offering direct marketing of regional products. If guests arrive by public transport they are eligible for discounts, and hotels must provide a free shuttle service to the nearest public transport station. Processing partners must purchase a minimum amount of produce that has been grown to conservation criteria such as four part crop rotation or including flowering strips in cereal farming.

The partner businesses are a driver for the sale of regional products grown with conservation in mind, which contribute to the preservation of the characteristic cultural landscape. The partners benefit in many 
ways. The BR administration advertises their products and provides funds for investing in buildings or equipment, for leaflets and certifications. They are also integrated into the regional as well as the national network of the Partner Initiative. Last but not least, they benefit from the quality promise of the initiative and the very positive image of the large protected areas within the German population.

\section{Outlook}

The young team of the BR administration is looking forward to cooperating with local actors in the exciting task of implementing the idea of sustainable regional development in actual projects. Promising approaches abound. A mayor from the region caught the spirit of optimism succinctly when he compared a BR with a happy marriage: convinced of your choice, you are curious how things will develop.

\section{Author}

Rüdiger Jooß

born 1969 in Stuttgart. Graduated in physical geography / landscape ecology. After a career in conservation research at the Institute of Landscape Planning and Ecology at the University of Stuttgart and in a ecological consulting firm, he joined the administration of Schwäbische Alb Biosphere Reserve in 2011, responsible for research, monitoring and conservation.

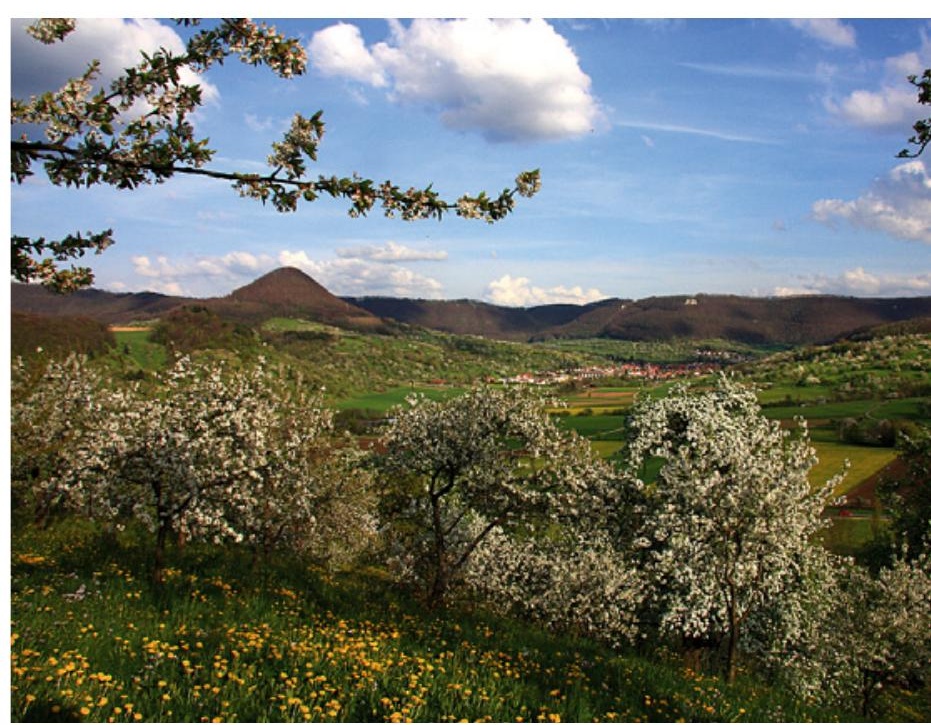

Figure 6-Albtrauf in spring. (C) D. Ruoff

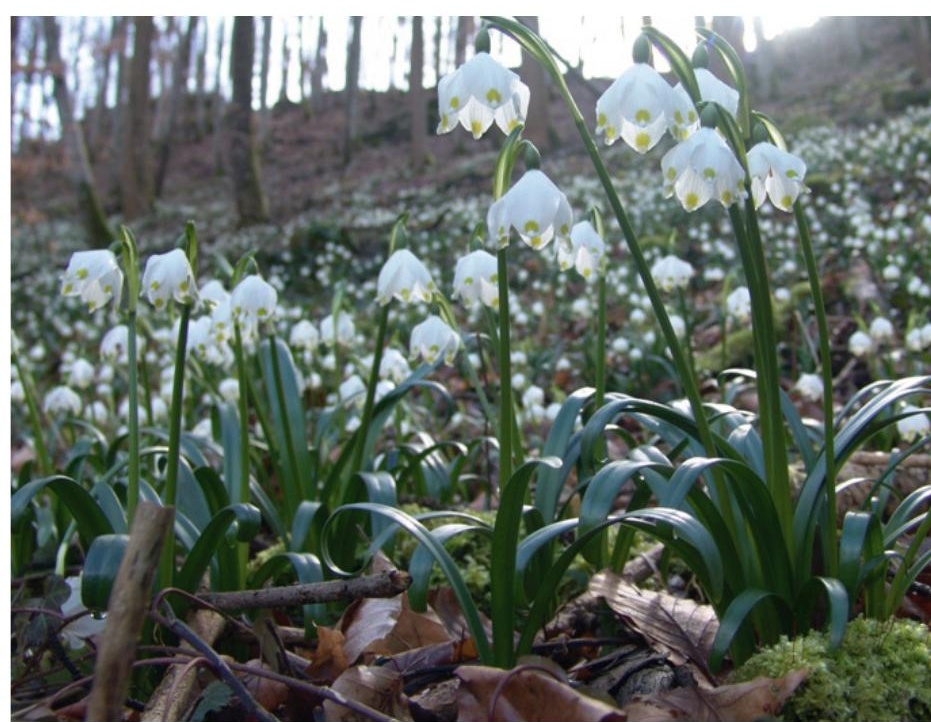

Figure 7 - Leucojum vernum. (C) K. Ströble 